\title{
Universal Credit: Assumptions, Contradictions and Virtual Reality
}

\author{
Jane Millar* and Fran Bennett** \\ *Institute for Policy Research, University of Bath, Claverton Down, Bath BA2 7AY \\ E-mail: j.i.millar@bath.ac.uk \\ ** Oxford Institute of Social Policy, University of Oxford, Barnett House, 32 Wellington Square, Oxford OX1 2ER \\ E-mail: fran.bennett@spi.ox.ac.uk
}

Universal Credit is a major change in the UK's social security system which will affect around eight million households by replacing six existing means-tested benefits and tax credits with a single benefit, based on income, assets and circumstances, and paid monthly. Much commentary about Universal Credit has supported the principle but raised concerns about delivery. This consensus about the principles and the focus on delivery have resulted in less attention being paid to key policy choices informing the design. This article examines two aspects of the design of Universal Credit: the aim to make Universal Credit as much 'like work' as possible, and the architecture of the means test. The focus here is the gap between the assumptions underlying the design of Universal Credit, on the one hand, and the research evidence about life on a low income, and in low-waged and often insecure employment, on the other. Finally, we discuss the most significant contradiction between the 'transformational' aim for Universal Credit, to help people achieve greater 'independence' from the state, and the realities of deepening and widening control of claimants' lives.

Key words: Universal Credit, implementation, means testing, behaviour.

\section{Introduction}

Universal Credit is a major change in the UK's social security system which, when fully implemented, will affect around eight million households (House of Commons Work and Pensions Select Committee, 2014) and half of all children (Finch, 2015). Universal Credit is a single benefit replacing six existing means-tested benefits and tax credits (Income Based Jobseeker's Allowance, Housing Benefit, Working Tax Credit, Child Tax Credit, Income Related Employment and Support Allowance and Income Support), with the amount based on income, assets and family circumstances, and delivered in the form of a single monthly payment. It was announced in 2010, the first payments were made in April 2013, and the aim is now to introduce it fully by early 2021.

Much discussion of Universal Credit seems to start with a statement along the lines of: 'it's a very good idea in principle'. For example:

The principles behind Universal Credit have widespread support, which we share. The Government has made significant progress in designing a system which will help ease the 
transition from benefits to work and it deserves to be congratulated for the progress it has made in this respect. (House of Commons Work and Pensions Select Committee, 2012)

Simplifying six benefits with different eligibility and withdrawal criteria into one benefit with a single withdrawal rate that is more easily understood makes sense ... As such, it appears there is considerable support for the underlying goals of Universal Credit across the political spectrum. (Finch et al., 2014, for Resolution Foundation; and see Finch, 2015)

The evidence suggests that there is considerable support among service users and stakeholder organisations for the principles of reform. (Tarr and Finn, 2012, for Inclusion)

A cross-party consensus about Universal Credit was also apparent in the 2015 general election manifestos, although with some caution about some of the details and the timing. ${ }^{1}$

The fact that there is apparently strong support from a wide range of interests and groups might be taken as a good sign: here is a policy that will not be buffeted by partisan and political differences. A simple benefit system with clear incentives is, it seems, something that everyone can agree on. But such a consensus about goals and objectives may be risky if it means that policy is not subject to detailed scrutiny of, on the one hand, the nature and accuracy of the underlying assumptions and, on the other, the practical realities of the effects of implementation. As Field and Forsey (2016: 73) note: 'The political historians may be interested in how a programme, so full of risk and potentially at such great cost, came to be the Coalition's flagship welfare reform policy with so little public and maybe cabinet debate.'

Many of those quoted above do temper their support for the principle of Universal Credit with concern about the challenges of delivery. In particular, there has been a substantial, and highly critical, focus on the information technology (IT) infrastructure by a range of commentators as the roll-out has proceeded at a slow pace, with significant IT failings and associated costs (Dugan, 2014; House of Commons Work and Pensions Select Committee, 2014; NAO, 2014; Click, 2015; House of Commons Public Accounts Select Committee, 2015). Others have examined areas such as the nature of the sanctions regime (Dwyer and Wright, 2014), the potential impact of monthly payments on household budgeting (Hartfree, 2014), and the possible effects of Universal Credit on work incentives (Finch et al., 2014). The Social Security Advisory Committee (2015) has recently identified a range of issues that it argues must be addressed as implementation moves from simpler to more complex cases. However, as Finch (2015) has pointed out, this focus on delivery has meant that the key underlying policy choices informing the design have received much less attention.

These two factors - the consensus about the principles and the focus on specific delivery problems - may thus be obscuring some of the fundamental issues of a design that, if not fit for purpose, will have adverse consequences for millions of people.

Here we examine two aspects of the design: the aim to make Universal Credit as much 'like work' as possible, and the architecture of the means test. The focus here is the gap between the assumptions underlying the design of Universal Credit, on the one hand, and the research evidence about life on a low income, and in low-waged and often insecure employment, on the other. This highlights how the policy design is out of step with the evidence. But perhaps that is the point? Universal Credit is not just about creating a new single benefit, it is also about a radical view of what the benefit system can do to change values and behaviour. We discuss this 'transformational' aim for Universal Credit (DWP, 2015b: 7) and explore the contradiction between the stated 


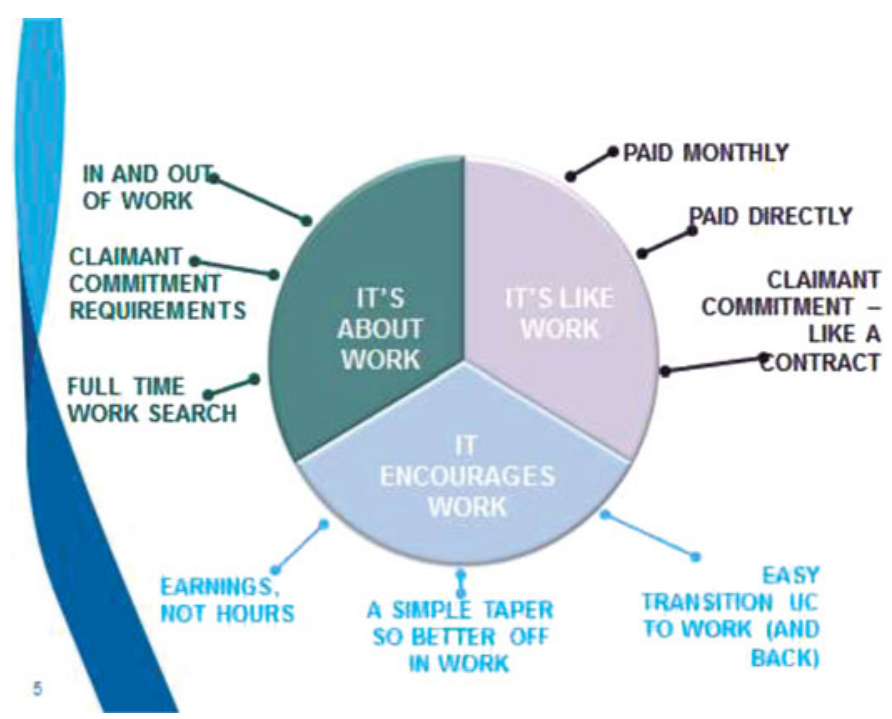

Figure 1. (Colour online) What's different about Universal Credit?

Source: Reproduced with permission from the Department for Work and Pensions (information current as of March 2015).

aim of greater 'independence' from the state and the practical realities of deepening and widening intrusion and control.

\section{Universal credit: 'like work'}

The Department for Work and Pensions (DWP) has been presenting Universal Credit to local authorities and voluntary groups. The DWP presentation, in Figure 1, sets out very clearly that Universal Credit is 'about work', it 'encourages work' and, crucially, it is 'like work' ('work' here meaning paid work and not unpaid work.)

As described in this presentation, being 'like work' means three things: that Universal Credit requires commitment in the same way that an employment contract does, that Universal Credit is paid directly, and that Universal Credit is paid monthly. This gives the policy the particular form it takes. The extent to which this really is 'like work' is, however, open to question.

First, the experience of claiming is intended to be like fulfilling a contract, in that those without employment must do work (in order to gain work) whilst in receipt of benefits and services. Officials have sometimes described this as the government being the employer of claimants: 'deliberately mirroring a contract of employment, the claimant commitment makes clear that welfare is no different from work itself' (DWP, 2015a: 5). But the contract imposed by Universal Credit ${ }^{2}$ carries very heavy sanctions and penalties, much more stringent than what might be expected in an employment contract. The new arrangements include as an ultimate sanction the loss of benefit for three years. Indeed, Universal Credit sanctions may be imposed not only on those jobless people allegedly not fulfilling their side of the contract but also on many part-time workers if they fail to actively seek to increase their working hours or pay levels. Dwyer and Wright (2014) describe this as a new 'welfare settlement', with profound consequences for social citizenship. 
Secondly, Universal Credit is paid direct to the claimant, as a wage would be. ${ }^{3}$ This change mainly affects Housing Benefit, which, under the current system, is often paid direct to the landlord, especially for those in social housing. This applies to those out of work, but is also the case for many people in work. So payment direct to the claimant does not represent the current reality of working life for many.

Thirdly, there is monthly payment (examined in more detail below). This is perhaps where the largest gap between assumptions and reality is found. The government says that three out of four employees are paid monthly, so monthly payment mimics life in work. But this means that one in four is not. And its own figures have shown that only about half those on under $£ 10,000$ per year are paid monthly - leading ministers to change their argument, to wanting to reflect the experience of full-time work instead. ${ }^{4}$ In addition, receiving a monthly salary of a fixed amount may be the usual experience of people in professional and managerial employment. But monthly (or more frequent) wage payments can and do vary for those with, for example, hourly pay rates and varying shift patterns, and/or with opportunities for overtime. Thus variation in wages is part of life for many workers, particularly in some sectors of the labour market (Hills et al., 2006; Ridge and Millar, 2008; Shildrick et al., 2012; Hartfree, 2014). Many people in this situation will also have a partner in work, whose wages are likely to be paid at a different time and possibly with a different frequency. And currently their life in work may also include receipt of benefits and tax credits at different intervals in addition to their wages.

\section{The design architecture: monthly assessment and payment}

As noted above, the aim is to make the experience of Universal Credit as much 'like work' as possible, with payment made monthly directly to those who fulfil their side of the contract. But unlike wages, because Universal Credit is a means-tested benefit its level also depends on other factors, including family circumstances, other streams of income and some forms of expenditure (such as housing and childcare costs). Decisions about responsiveness - how and when to take account of changes in income and circumstances - are key issues in the design of any means-tested benefit system (Whiteford et al., 2003). Universal Credit operates on the basis of a monthly assessment, and the choice of a month as the key time period will have significant consequences for recipients. It seems that ministers may not have realised the full implications of this feature. Indeed, Lord Freud sounded convinced in 2013 that the development by HM Revenue and Customs of 'real time information' (RTI), to record changes in wages much more speedily, means that Universal Credit will be responsive to people's real needs every month (Sainsbury, 2014: 40). ${ }^{5}$

It is true that there is much room for improvement in relation to responsiveness, as modifications of tax credits in particular in response to changes in circumstances can cause serious problems for many claimants (Millar, 2011). However, even if they work in practice, the RTI arrangements for Universal Credit only cover wages and any changes to them. As Hills et al. (2006) found when investigating changes in incomes in relation to tax credits, these can be multiple and often relate to other sources in addition to pay. Low-income families also tend to experience frequent changes in other circumstances, such as housing costs and number of people in the household. Millar and Ridge (2011: EV60, para. 8) note: 'the experience of the delivery of tax credits does not appear to have been fully taken into account and in particular the extent to which the Universal Credit 
system will have to cope with changes in circumstances seems to be somewhat underestimated'. They cite Baroness Hollis, former minister responsible for tax credits: 'It is fair to say that when we introduced the Tax Credits Bill we did not predict that 50 per cent of lone parents would undergo more than a dozen changes in circumstance a year.' And they point out that many people do not report changes in circumstances immediately, for a range of reasons, and that many changes are inherently short term or unstable (such as children in separated families living with one parent and then moving to live with the other).

This knowledge about the realities of low-income families' lives is critical - in part because Universal Credit is not just paid monthly but is also a monthly benefit. Most importantly, this means that it is assessed as a monthly benefit. This is difficult to comprehend from the perspective of the current system. But key features include there being no daily or weekly rate of Universal Credit, and assessment being based on the circumstances that apply on only one day in each month. This does not just result in no entitlement to Universal Credit for any self-contained period shorter than a month, it also means that the circumstances applying on the assessment date each month are treated as though they applied to the previous month as a whole (not pro rata for the part of the month to which they actually apply - as happens with changes in wages, via the RTI system) (Bennett, 2014). This may apply to aspects such as changes in housing costs, additions to or reductions in the number of people in the household.

This arrangement may have either positive or negative consequences financially for the people concerned. Those who have a new baby shortly before their assessment date will have an advantage, for example, as they get almost a month's extra benefit. Those whose teenage daughter leaves the household to live independently just before the assessment day, on the other hand, lose out, because they are treated as though she had left at the beginning of the month. But crucially, whether positive or negative, the change in the amount of Universal Credit paid will only in rare cases mirror the change in individual/family needs in reality, and income will therefore match circumstances less closely. This is likely to make it more difficult to, for example, budget money on a monthly basis, set up direct debits, or indeed see the impact on entitlement of changes in wages all of which are amongst the central aims of Universal Credit. ${ }^{6}$

So for calculating Universal Credit, only twelve days in each year will be important for claimants with a continuing claim. And regardless of when claimants report a change of circumstances, as long as this is before their assessment date it will apply for the whole of the month prior to that date. The government argues that this arrangement is meant to ensure that people have the right amount of resources for their needs for the coming month. But this rationale suggests that Universal Credit is paid in advance, whereas it is in fact paid in arrears for the month that has already finished. In addition, it is not clear that there will be a detailed breakdown of the make-up of the monthly Universal Credit payment as it changes over time. It would therefore not be surprising, in our view, if claimants become rather confused (see also WBG, 2012b).

The monthly in arrears payment means that the amount of Universal Credit does not correspond to current circumstances, even for RTI wages. Monthly payment also raises issues about the fit (or lack of fit) with the household budgeting practices of those on low incomes. Monthly payments could suit some claimants who pay their rent or mortgage monthly. In practice, however, Universal Credit is likely to disrupt family budgeting patterns for many by removing the 'vital set of links in a chain of money management' 
(Daly and Kelly, 2015: 176). These features in the current system take the form of labelling of benefits, differing payment intervals and different recipients for different benefits/tax credits etc. - together with the psychological boost of receiving benefit payments on certain days, thus 'bridging' life on a low income. These might be seen as unintended consequences of the current system, rather than design features intended to support budgeting. Nevertheless, as Millar (2015) argued:

There will be no flexibility of different payments being received on different days of the week or month, as there is now. Universal Credit is one basket, with all the eggs in it, which makes people vulnerable if anything goes wrong. If there is only one system, and that system lets you down, then hardship will inevitably result, unless families and others are able to help pick up the pieces.

This has important implications for budgeting. Women are more likely to manage the household budget in low-income families, and to be responsible for the more frequently purchased items (daily/weekly), so there is concern that this will have a disproportionate impact on them (WBG, 2012a). Reporting on only the views of the main claimant (more likely to be men), in research into potential claimants' perspectives on Universal Credit, Tu and Ginnis (2012) found that only one in ten thought that monthly budgeting would make things easier. Two-thirds of the total sample were already running out of money before the end of the week/month always, most of the time, more often than not or sometimes.

As Daly and Kelly (2015: 176) starkly conclude, on the basis of their recent qualitative research with low-income families with children in Northern Ireland: 'All the evidence obtained through this study suggests not a gap but a chasm between the patterns of money management practised in the families studied and the planned reforms.' Thus the assumptions underpinning the design of Universal Credit are divorced from what we know from research on life in low-waged and often insecure employment (or living on a low income out of work). This suggests a major disconnect between research evidence and policy, and we would suggest strays far from the tenets of 'what works?' as a key driver for policy design. Of course, there are numerous examples of a gap between policy and evidence; Universal Credit is not alone in this respect. In the framework proposed by King and Crewe (2013), this can be interpreted as a 'blunder', defined as a mistake which leads to failure to achieve stated goals, or which achieves goals but at a disproportionately high cost, or with significant unintended and negative consequences. Their case studies cover a number of areas, including several from within social security/taxation - the Poll Tax, pension mis-selling, Child Support, and tax credits - and in a postscript, they suggest that Universal Credit has the hallmarks of a 'blunder-in-waiting'. Universal Credit could be seen as an example of what they call a 'cultural disconnect', in which policy-makers assume that people live as they themselves do and, in the case of social security, do not readily understand the realities of life for people without employment and income stability and with few cushions against adversity. This may indeed be the case. But a 'blunder' implies a genuine mistake, and one that could therefore be reversed if proper account were taken of the evidence.

By contrast, Slater (2014) argues that, in some policy areas, 'ignorance' of the evidence may be deliberate and can be crucial to the way in which policy change is legitimised. He draws on research on the tobacco industry's tactics in respect of the evidence on the health hazards of smoking and applies this to the 'broken Britain' case for welfare reform. He argues that it is important to 'expose and scrutinize the institutional 
ignorance that lies at [the core of the Welfare Reform Act 2012]; an ignorance that is not one of blissful unawareness or innocent absence of knowledge, but rather of rational calculation' (op cit, 960). This implies that lack of concern about evidence is not so much a blunder, or lack of attention, but a deliberate tactic to support the chosen policy direction. The avowed goal of Universal Credit is not just to change the benefit system; it is also to transform values and behaviour.

\section{Transforming values and behaviour}

Ministers have made clear that they see their vision for Universal Credit as transformational (DWP, 2015a: 27; DWP, 2015b: 7; ICF International, 2015): 'what Universal Credit is really about is a sweeping cultural change' [for Jobcentres, businesses, local authorities, and] ... '[m] ost importantly of all, we know that each and every statistical shift marks a life that has been transformed - a person now with brighter prospects and hope renewed' [DWP, 2015a: 3-4]. The tone of DWP reporting on outcomes for new Universal Credit claimants is almost messianic, and could certainly be described as loaded: 'Thus for all those who are able, it no longer makes more sense to sit on benefits than enter work rather, the right choice for individuals is also the logical one'. (DWP, 2015a: 7).

Universal Credit seems designed to suit the people that ministers believe claimants should become, rather than starting from where they are now. This aim to achieve transformational cultural change underpins the strong focus on conditionality, with the aim of strengthening connections to the labour market through enforcement of work requirements. Transforming behaviour and values also underpins other aspects of the design. So, for example, the features discussed above - payment of Housing Benefit direct to social housing tenants rather than their landlords, and monthly payment - were modelled on '(what is seen as) a majority way of life [as Ministers explained to Select Committees], rather than being shaped around the priorities and coping mechanisms developed by those living on low incomes' (Bennett, 2014, cited in FIC, 2015: 14).

The government argues that Universal Credit 'fosters independence and personal responsibility' (DWP, 2014), in part through 'encouragement for claimants to manage their finances, while in and out of work'. Doing so 'is important in minimising the difference between paid employment and being on benefits and effectively removes a key barrier to moving back into work' (DWP, 2015a: 32). This is a positive vision, as well as a desired cultural change. Once on a monthly benefit regime, claimants could take advantage of the bulk purchases, direct debits and reductions available to those with monthly salaries. The Financial Inclusion Commission (2015), for example, picking up a theme advanced by ministers, thought that monthly payments could help people to overcome the 'poverty premium' (Save the Children, 2011), which can result in those with lower incomes often having to pay more for services and goods.

The government has made some attempts to find commercial solutions to support the changes in budgeting that will be required - for example, trying to persuade the private sector to provide 'jam jar accounts', so that claimants could allocate their Universal Credit payment to different sections of their account - ironically echoing to some extent the current labelling and differentiation of benefits and tax credits. However, such products as do exist are costly and limited in scope (The Guardian, 2015). A commercial solution therefore does not seem to be forthcoming. The DWP has instead put resources into devising a support structure for budgeting - although it would like to see such help as 
only temporary for most, as part of their transition to the new system. This is now part of 'universal support delivered locally', and will involve many local authorities and voluntary organisations in helping claimants with personal budgeting (as well as digital claiming and reporting etc.). Instead of building on the strengths of the ways in which many of those on low incomes currently manage their money, Universal Credit thus creates a new system that removes existing supports to budgeting. It labels those for whom this does not work well as exceptions (often, indeed, in the language of official documents, 'vulnerable', or not managing well. And then sets up a new support system to assist them with budgeting a monthly income that, because of the inherent design of Universal Credit, varies in ways that claimants may find difficult to predict or comprehend.

Overall an elaborate edifice is being built which seems to undermine the principles of simplicity and clarity and which may exacerbate claimants' difficulties, or increase their dependence on/control by intermediaries. This could be seen as generating a contradiction between the end - a desire to foster independence - and the means to bring it about, which involves intervention and some control over budgeting for at least a sizable minority of claimants. We now turn to examining how this contradiction works itself out in the primary arena of government goals for Universal Credit, which involve claimants' relationships with paid work, and which apply to most claimants.

\section{A contradiction: independence and control}

Ministers argue that 'above all for individuals, Universal Credit marks a complete shift in the whole nature of welfare, no longer trapping people in dependency but providing the incentive and support to secure a better future for themselves and their families' (DWP, 2015a: 3). Such claimants are 'on a journey from dependency to independence' (DWP, 2015a: 7; see also NAO, 2014: 50). Similarly, in an interview about Universal Credit (Sainsbury, 2014: 43), Lord Freud, Minister for Welfare Reform, expresses his aspiration that Universal Credit would be 'giving people back control of their lives'.

However, there is a problem here. This commitment to independence is directly contradicted by the increased control inherent in the Universal Credit design. The current direction of social security policy for people of working age goes beyond the 'work is good for you' approach of recent Labour governments (1997-2010). As under Labour, work is indeed seen as good for you, and a 'work first' approach still underpins the UK's employment services. But the goal now goes beyond that: people should always be aiming to be independent of the state, not reliant upon it in any way. The label of 'dependency' is thus extended to those in work claiming state support (Bennett, 2012, drawing on Lister and Bennett, 2010). Work should take people away from 'welfare' and they should (learn to) stand on their own two feet:

One of the key objectives of DWP's wider labour market reforms is to deliver an in-work service, offering support to Universal Credit claimants as they explore how they can increase their earnings and become more independent. (DWP, 2015a: 28)

But this creates a paradox. Using wage supplements to help 'make work pay' and augmenting incentives in any case extends state support into the working population and thus undermines the goal of independence, if interpreted in this way. The intention is to deliver Universal Credit in a way that mimics the wages system and thereby induce behaviour seen as more appropriate to being in employment. The contradiction here, 
however, is that the intrusion and control embedded in the design are substantial and extend to both more people and more aspects of their lives. This involves extending conditionality not just to all those in work earning less than a certain amount but also for the first time fully to partners with children (Fawcett Society, 2015). ${ }^{7}$ In addition, the sanctions for failure to comply will in practice affect the whole of the Universal Credit payment, not just the allowances for adults, as currently. Although the reductions for non-compliance are applied only to the standard personal rate of Universal Credit, there is only one payment and so any reductions in reality apply across the board. Thus three radical increases in the scope of conditionality are involved - though commentators have by and large focused only on the extension of conditionality to those in work.

Once claimants have found work, the DWP (2015: 6) explains: 'Work Coaches in Jobcentres also have the remit to help individuals progress onwards and upwards. Thus the relationship becomes far more personal, with Work Coaches looking to help shape and support their claimants' career progression and long-term ambitions.' The government is keen to describe in-work conditionality as 'in-work support' and is currently coordinating experiments to test different approaches. Intervention in claimants' lives is not limited to the DWP. Local authorities involved in the pre-Universal Credit pilots and social landlords in the direct payments scheme have been working closely with claimants to encourage them into employment and/or help them manage their money (DWP, 2015a: 6) - though they have indicated that this level of intensive support may not be feasible with the larger numbers in full roll-out. Alternative payment arrangements for Housing Benefit can now be made with one month's arrears, and a managed payment to the landlord with two months' arrears. From November 2014, in addition, an increased rate of deductions can be made to repay such arrears (according to the government, to 'help claimants clear their debts more quickly so they can focus on moving into employment' (DWP, 2015a: 33). Data sharing will also now be possible between the DWP and social landlords, to reach claimants with potential budgeting problems (DWP, 2015a: 33), as well as debt, housing and drug and alcohol issues (lain Duncan Smith MP, House of Commons Hansard 2015). It all seems a far cry from the hands off future envisaged by the government for claimants, becoming independent of state support and managing their money in the mainstream (Bennett, 2014). And whilst they are still Universal Credit claimants, they will be excluded from some government measures that benefit those with higher incomes. For example, the $£ 6,000$ capital rule has been extended from those out of work to include those in work on Universal Credit, with all savings above this used to reduce benefit income whilst those with ISAs may benefit from an increase in the limit for what can be saved. And, as the Resolution Foundation and others have noted, those on means-tested benefits get a much reduced advantage from the real increases in the personal tax allowance (if they earn enough to pay tax), because of the withdrawal rate. ${ }^{8}$

Moreover, some commentators (e.g. FPI, 2011; Bennett, 2012; Women's Budget Group: www.wbg.org.uk) have also observed that, while the government is keen to attack 'welfare dependency', it seems much less concerned about economic dependence within the family. UK means-tested benefits and tax credits involve the amalgamation of needs, and income and other resources, in a family means test; and one person's decisions and outcomes depend on their partner's. But, in addition to the worsened position for many 'second earners' compared with the current tax credits system (Finch, 2015), Universal Credit also involves further dependence, in that if one partner will not sign the claimant commitment, the couple's claim as a whole fails. 


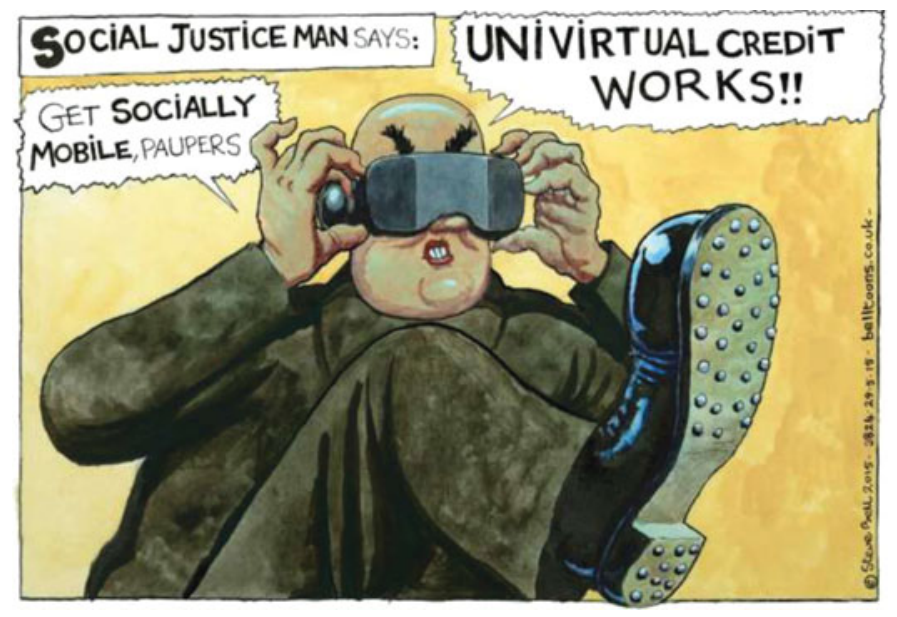

Figure 2. (Colour online) Steve Bell's cartoon on Iain Duncan Smith's benefits shakeup Source: The Guardian, 29 May 2015, reproduced with permission of Steve Bell.

Finally, another paradox, as some commentators suggest, is that, despite in-work conditionality, the visible subsidy provided by Universal Credit to low-paid and part-time work could encourage an ever-more 'flexible' labour market. For example, claimants and/or their employers may seek to reduce weekly hours below the sixteen hitherto required for entry to tax credits (Alakeson et al., 2015; Finch, 2015). The government is presumably relying on the impact of in-work conditionality on claimants to counter this.

\section{Evidence, policy and virtual reality}

As we have argued, Universal Credit fails to connect with the realities of life, particularly life on a low income, not least because it intended to change that reality. This aspect of Universal Credit is captured by Steve Bell, in the cartoon reproduced below (Figure 2). Here is lain Duncan Smith MP (then Secretary of State for Work and Pensions) looking at the world through virtual reality glasses, pronouncing that the policy works, and shouting about changing the 'paupers'.

But people cannot change the labour market as individuals; all they can do is to try and change their position within it. And that is often a long-term project, and one requiring not just individual aspiration but the right conditions and opportunities. The same is true of other areas affecting incomes and living standards, such as the market in utilities, the provision of financial services, the housing market and so on. Seeking to change people without paying sufficient attention to the context in which they make choices and decisions puts a lot of pressure on individuals. Even if the IT and other delivery issues can be resolved, the impact of Universal Credit, with all its underlying assumptions and aims, will fall upon those individuals and families as they struggle with systems beyond their control.

Income security - knowing how much money you will have and when you will have it - is important in general (Orton, 2015), and especially to low-income families. Starting to claim benefits, for example because of unemployment or becoming a lone 
parent, is a time of great income uncertainty, and so is starting work. Even for those in work, changes in wages and other circumstances can also create financial uncertainty. Universal Credit aims to make these transitions less risky and the goal - or hope - is that a single benefit will indeed reduce confusion and make the system more transparent. However, as we have discussed, there are aspects to the design that militate against creating income security, including the ongoing monthly assessment, the lack of detailed breakdown of the award and the low level of the disregard through the work allowance. In addition, while Universal Credit removes features of benefits that research has shown help some claimants to keep better control of their finances, these same claimants may be simultaneously trying to cope with unprecedented scrutiny and control of their daily lives, aiming to move them towards employment/more employment and in many cases certain budgeting behaviours in addition. Ministers have also seen Universal Credit, and indeed the social security system in general, as providing the opportunity to deal with some of the other behavioural problems that they believe to be fundamental causes of poverty, such as addiction. ${ }^{9}$ The interaction of social housing providers with their tenants during the demonstration projects involving payment of housing benefit direct, for example, was perceived as facilitating more intensive contact with a view to such intervention.

What next for Universal Credit? The Conservative government is pressing ahead with implementation, but the timetable for the roll-out continues to be revised. The devolved administrations have some opportunities to vary the operation of Universal Credit, although the benefit as a whole remains a reserved power for the Westminster government. ${ }^{10}$ Most importantly, there are very significant cuts in support, already applied to tax credits and benefits, and further cuts are already planned for Universal Credit (House of Commons Library, 2016: House of Commons Hansard, 2016). By 2019-20, the level of financial support offered is likely to be considerably lower than it is now, perhaps not worth the high transaction costs of the shift to a new system. Universal Credit promises much but, at the same time, is too limited. The concept of a single, simple benefit focused on the promotion of work incentives is too narrow a principle for the whole of the social security system for working-age people. The design of Universal Credit is too far removed from the realities of life on a low income. The delivery is far from simple, and will become more complex as more contingencies have to be taken into account. Field and Forsey (2016: 124) have recently argued that there is a need for a 'thorough review of in-work benefits, which looks beyond Universal Credit and takes as its starting point the full protection of lower paid workers with children'. We agree with the need for a thorough review, but would argue that the issues are broader than the protection of lower-paid workers with children. Fundamental questions remain outstanding - about the multiple functions of social security for working-age people (both in and out of work), about the basis of qualification for benefits (in particular whether this should involve a means test or not) and about the unit of assessment (whether this should be an individual or a family). Key issues about the purpose and nature of social security provision in the twenty-first century in the UK are still to be resolved.

\section{Notes}

1 See also Judge (2013) for the Child Action Poverty Group (CPAG) and the Trade Union Congress (TUC); and Goulden (2015) for Joseph Rowntree Foundation. The Labour Party proposed a 'pause' for reflection, but the Green Party was the only clear dissenting voice, describing Universal Credit as 'a 
disaster waiting to happen' - and for the longer term, proposing a very different (non-means-tested, unconditional) basic income.

2 Due to the delayed introduction of Universal Credit, the 'claimant commitment' applies to some other benefits in addition.

3 This is of course rather different in couple households in which the claim is joint but only one payment of Universal Credit is usually made to one account.

4 Parliamentary Under Secretary of State for Work and Pensions, House of Commons Hansard, 9.5.12, col. 123 .

5 It is perhaps worth noting, however, that this may also mean that the 'poverty trap' (reduced benefit as well as increased taxation when other income increases) is more visible to claimants, especially combined with the single taper under Universal Credit (Bennett, 2012). In addition, the government has introduced a measure that includes recent income earned (or losses made) in the calculation of Universal Credit for new claimants (Bennett, 2014). Both these features may mean that there are clear downsides to the responsiveness described here.

6 In addition, further complexities arise because the arrangements for 'passported benefits' (such as free school meals) have not yet been developed in detail (SSAC, 2015); and, as noted by many, council tax support will be worked out on a completely different system, by a different organisation at local authority level, and be paid separately and withdrawn at a different rate.

7 Joint claims for Jobseeker's Allowance introduced conditionality for both partners, but to date only for those without children, although legislation would allow extension to those with children.

8 We are grateful to an anonymous reviewer for drawing our attention to these points.

9 Oral Statement by lain Duncan Smith MP, House of Commons Hansard, 1 July 2015, col. 1505: http://www.publications.parliament.uk/pa/cm201516/cmhansrd/cm150701/debtext/150701-0002.htm\# 15070135000003.

10 The Smith Commission proposed that Scotland should have powers over the frequency of payments, the payee (thus making splitting payments between partners in couples easier) (Engender, 2015) and direct payment of the housing element to landlords (Devolution (Further Powers) Committee, 2015). Wales has to date not pursued similar powers, though it will follow closely the experience in Scotland (personal communication from Victoria Winckler, Bevan Foundation, May 2015). In Northern Ireland, divisions of opinion over such issues were one of the reasons for the stalemate over the Welfare Reform Bill (McKeever, 2015); at the time of writing, agreement has been reached but it is not yet clear what measures will be taken in NI to ease the impact of welfare reforms, including Universal Credit.

\section{References}

Alakeson, V., Brewer, M. and Finch, D. (2015) Credit Where it's Due? Assessing the Benefits and Risks of Universal Credit, London: Resolution Foundation.

Bennett, F. (2012) 'Universal Credit: overview and gender implications', in M. Kilkey, G. Ramia and K. Farnsworth (eds.), Social Policy Review 24: Analysis and Debate in Social Policy 2012, Bristol: The Policy Press, pp. 15-34.

Bennett, F. (2014) 'Written evidence to Financial Inclusion Commission', http:// financialinclusioncommission.org.uk/evidence/written [accessed 25.05.2015].

Click, B. (2015) 'Government and Labour trade accusations and insults over Universal Credit progress', Computer Weekly, http://www.computerweekly.com/news/2240239284/Government-and-Labourtrade-accusations-and-insults-over-Universal-Credit-progress [accessed 25.05.2015].

Daly, M. and Kelly, G. (2015) Families and Poverty: Everyday Life on a Low Income, Bristol: The Policy Press.

Department for Work and Pensions (DWP) (2014) Universal Credit at Work, London: Department for Work and Pensions.

Department for Work and Pensions (DWP) (2015a) Universal Credit at Work: Spring 2015, London: Department for Work and Pensions. 
Department for Work and Pensions (DWP) (2015b) Universal Credit at Work: December 2015, London: Department for Work and Pensions.

Devolution (Further Powers) Committee, Scottish Parliament (2015) New Powers for Scotland: An Interim Report on the Smith Commission and UK Government's Proposals, SP Paper 720, Third Report, Session 4 (2015), Edinburgh: APS Group Scotland for Scottish Parliament Corporate Body.

Dugan, E. (2014) 'Benefit reforms: one year on, universal credit is not working', The Independent, 18 May, http://www.independent.co.uk/news/uk/politics/benefit-reforms-one-year-on-universal-credit-is-notworking-9391283.html [accessed 25.05.2015].

Dwyer, P. and Wright, S. (2014) 'Universal credit, ubiquitous conditionality and its implications for social citizenship', Journal of Poverty and Social Justice, 22, 1, 27-35.

Engender (2015) A Widening Gap: Women and Welfare Reform, Edinburgh: Engender.

Family and Parenting Institute (FPI) (2011) Families in an Age of Austerity: How Tax and Benefit Reform Will Affect UK Families, London: Family and Parenting Institute.

Fawcett Society (2015) Where's the Benefit? An Independent Inquiry into Women and Jobseeker's Allowance, London: Fawcett Society.

Field, F. and Forsey, A. (2016) Fixing Broken Britain? An Audit of Working-Age Welfare Reform since 2010, London: Civitas.

Financial Inclusion Commission (FIC) (2015) Financial Inclusion: Improving the Financial Health of the Nation, London: Financial Inclusion Commission.

Finch, D. (2015) Making the Most of UC: Final Report of the Resolution Foundation Review of Universal Credit, London: Resolution Foundation.

Finch, D., Corlett, A. and Alakeson, V. (2014) Universal Credit: A Policy under Review, London: Resolution Foundation, http://www.resolutionfoundation.org/wp-content/uploads/2014/09/Universal-Credit-Apolicy-under-review1.pdf [accessed 25.05.2015].

Goulden, C. (2015) 'What future for Universal Credit?', blog for Joseph Rowntree Foundation, 20 April, http://www.jrf.org.uk/blog/2015/04/universal-credit-progress [accessed 25.05.2015].

Guardian, The (2015) 'Need to budget? Open a jam jar account', 16 May.

Hartfree, Y. (2014) 'Universal Credit: the impact of monthly payments on low income households', Journal of Poverty and Social Justice, 22, 1, 15-26.

Hills, J., Smithies, R. and McKnight, A. (2006) Tracking Income: How Working Families' Incomes Vary Through the Year, CASEreport 32, London: Centre for Analysis of Social Exclusion, London School of Economics.

House of Commons Hansard (2015), Debates 1 July 2015.

House of Commons Hansard (2016), Debate on Universal Credit work allowance, 6 January, cols. 290348.

House of Commons Library (2016) Universal Credit Changes from April 2016, Briefing Paper Number CBP7446, 5 January 2016, http://researchbriefings.parliament.uk/ResearchBriefing/ Summary/CBP-7446\#fullreport [accessed 14.01.2016].

House of Commons Public Accounts Select Committee (2015) Universal Credit: Progress Update, Forty-Second Report of Session 2014-15, HC 810, London: The Stationery Office, http://www.publications.parliament.uk/pa/cm201415/cmselect/cmpubacc/810/81002.htm [accessed 25.05.2015].

House of Commons Work and Pensions Select Committee (2012) Universal Credit Implementation: Meeting the Needs of Vulnerable Claimants, Third Report, Session 2012-13, HC 576, London: The Stationery Office.

House of Commons Work and Pensions Select Committee (2014) Universal Credit Implementation: Monitoring DWP's Performance in 2012-13, Fifth Report, Session 2013-14, HC 1209, London: The Stationery Office, http://www.publications.parliament.uk/pa/cm201314/cmselect/ cmworpen/1209/1209.pdf [accessed 25.05.2015].

ICF International (2015) Key Policy Messages from the Peer Review on 'Universal Credit' (The UK: 30 November-1 December 2015), Mutual Learning Programme, DG Employment, Social 
Affairs and Inclusion, Brussels: European Commission, http://ec.europa.eu/social/main.jsp?langld= en\&catld $=89 \&$ newsld $=2302 \&$ furtherNews=yes [accessed 24.01.2016]

Judge, L. (2013) Will Universal Credit Work?, London: Trades Union Congress, http://www.cpag. org.uk/sites/default/files/TUC-CPAG-UC-report-0413.pdf [accessed 25.05.2015].

King, A. and Crewe, I. (2013) The Blunders of our Governments, London: OneWorld Publications.

Lister, R. and Bennett, F. (2010) 'The new "champion of progressive ideals"? Cameron's Conservative Party: poverty, family policy and welfare reform', Renewal, 18, 1, 84-109.

McKeever, G. (2015) 'Welfare reform and devolution', Journal of Social Security Law, 22, 1, 16-19.

Millar, J. (2011) Tax credits: a close-up view. Journal of Poverty and Social Justice, 19, 1, 39-50.

Millar, J. (2015) 'Policy Briefing: Universal Credit - is it worth it?', Discover Society, 16, 3 January, http://www.discoversociety.org/2015/01/03/policy-briefing-universal-credit-is-it-worth-it/ [accessed 24.05.2015].

Millar, J. and Ridge, T. (2011) 'Written evidence', House of Commons Work and Pensions Committee White Paper on Universal Credit Oral and written evidence, HC 473, The Stationery Office, London, http://www.publications.parliament.uk/pa/cm201011/cmselect/cmworpen/743/743.pdf.

National Audit Office (NAO) (2014) Universal Credit Progress Update, HC 786, Session 2014-15, London: The Stationery Office.

Orton, M. (2015) Something's Not Right: Insecurity and an Anxious Nation, London: Compass.

Ridge, T and Millar, J (2008) Work and Well-being over Time: Lone Mothers and Their Children, DWP Research Report 536, Leeds: Corporate Document Services.

Sainsbury, R. (2014) 'Talking Universal Credit: in conversation with Lord Freud, Minister for Welfare Reform', Journal of Poverty and Social Justice, 22, 1, 37-44.

Save the Children (2011) The UK Poverty Rip-off: The Poverty Premium 2010, London: Save the Children.

Shildrick, T., Macdonald, R., Webster, C. and Garthwaite, K. (2012) Poverty and Insecurity: Life in Low-pay, No-pay Britain, Bristol: The Policy Press.

Slater, T. (2014) 'The myth of "Broken Britain": welfare reform and the production of ignorance', Antipode, 46, 4, 948-69.

Social Security Advisory Committee (SSAC) (2015) Universal Credit: Priorities for Action, SSAC Occasional Paper No. 15, www.gov.uk/government/publications/ssac-occasional-paper-15-universal-creditpriorities-for-action [accessed 21.07.2015].

Tarr, A. and Finn, D. (2012) Implementing Universal Credit: Will the Reforms Improve the Service for Users? London: Inclusion, http://www.cesi.org.uk/publications/implementing-universalcredit-will-reforms-improve-service-users [accessed 25.05.2015].

Tu, T. and Ginnis, S. (2012) Work and the Welfare System: A Survey of Benefits and Tax Credits Recipients, Research Report 800, London: Department for Work and Pensions.

Whiteford, P., Mendelson, M. and Millar, J. (2003) Timing it Right? Tax Credits and How to Respond to Income Changes, York: Joseph Rowntree Foundation.

Women's Budget Group (WBG) (2012a) 'Progress towards the implementation of Universal Credit', Written evidence submitted by the WBG to the Work and Pensions Select Committee, HC 576, http://www.publications.parliament.uk/pa/cm201213/cmselect/cmworpen/writev/576/m02.htm [accessed 25.05.2015]; see www.wbg.org.uk for other briefings on Universal Credit.

Women's Budget Group (WBG) (2012b) 'Progress towards the implementation of Universal Credit', Supplementary written evidence submitted by the WBG to the Work and Pensions Select Committee, HC 576, http://www.publications.parliament.uk/pa/cm201213/cmselect/cmworpen/ writev/576/m02a.htm [accessed 25.05.2015]. 